\title{
Kombinasi Algoritma Backpropagation Neural Network dengan Gravitational Search Algorithm Dalam Meningkatkan Akurasi
}

\author{
Miftahul Falah*, Dian Palupi Rini, Iwan Pahendra \\ Fakultas Ilmu Komputer, Magister Ilmu Komputer, Universitas Sriwijaya, Palembang, Indonesia \\ Email: 1," miftahulfalahsia@gmail.com, ${ }^{2}$ dian.palupi.rini@gmail.com, ${ }^{3}$ iwanpahendra@gmail.com \\ Email Penulis Korespondensi: miftahulfalahsia@gmail.com
}

\begin{abstract}
Abstrak-Memprediksi penyakit biasanya dilakukan berdasarkan pengalaman dan pengetahuan dokter. Diagnosis penyakit secara tradisional seperti itu kurang efektif dilakukan. Pengembangan diagnosis medis berdasarkan pembelajaran mesin dalam hal prediksi penyakit memberikan diagnosis yang lebih akurat dibandingkan dengan cara tradisional. Dalam hal memprediksi penyakit dapat menggunakan jaringan saraf tiruan. Jaringan saraf tiruan terdiri dari berbagai macam algoritma salah satunya Algoritma Backpropagation. Dalam makalah ini diusulkan sistem prediksi penyakit menggunakan algoritma Backpropagation. Algoritma Backpropagation sering digunakan dalam prediksi penyakit, tetapi algoritma Backpropagation terdapat sedikit kekurangan yaitu cenderung lama dalam mendapatkan nilai akurasi yang optimum. Oleh karena itu diperlukan kombinasi dengan menggunakan algoritma yang dapat mengatasi kekurangan algoritma Backpropagation tersebut dengan menggunakan keberhasilan algoritma Gravitational Search Algorithm (GSA) yaitu dapat mengatasi konvergensi lambat dan masalah minimum lokal yang terdapat di algoritma Backpropagation. Sehingga penulis mengusulkan untuk mengkombinasikan algoritma Backpropagation menggunakan algoritma Gravitational Search Algorithm (GSA) dengan harapan dapat meningkatkan hasil akurasi yang lebih baik dibandingkan hanya menggunakan algoritma Backpropagation saja. Hasil yang didapatkan menghasilkan tingkat akurasi yang lebih tinggi dengan jumlah iterasi yang sama dibandingkan hanya menggunakan Backpropagation saja. Dapat dilihat pada percobaan pertama data penyakit kanker payudara dengan parameter yaitu hidden layer sebesar 5, learning rate sebesar 2 dan iterasi sebanyak 5000 menghasilkan akurasi sebesar 99,3\% dengan error $0.7 \%$ pada Algoritma Backpropagation, sedangkan pada kombinasi BP \& GSA mendapat akurasi sebesar $99.68 \%$ dengan error sebesar $0.32 \%$.
\end{abstract}

Kata Kunci: Kombinasi; Akurasi; Jaringan Saraf Tiruan; Backpropagation; Gravitational Search Algorithm (GSA)

\begin{abstract}
Predicting disease is usually done based on the experience and knowledge of the doctor. Diagnosis of such a disease is traditionally less effective. The development of medical diagnosis based on machine learning in terms of disease prediction provides a more accurate diagnosis than the traditional way. In terms of predicting disease can use artificial neural networks. The artificial neural network consists of various algorithms, one of which is the Backpropagation Algorithm. In this paper it is proposed that disease prediction systems use the Backpropagation algorithm. Backpropagation algorithms are often used in disease prediction, but the Backpropagation algorithm has a slight drawback that tends to take a long time in obtaining optimum accuracy values. Therefore, a combination of algorithms can overcome the shortcomings of the Backpropagation algorithm by using the success of the Gravitational Search Algorithm (GSA) algorithm, which can overcome the slow convergence and local minimum problems contained in the Backpropagation algorithm. So the authors propose to combine the Backpropagation algorithm using the Gravitational Search Algorithm (GSA) in hopes of improving accuracy results better than using only the Backpropagation algorithm. The results resulted in a higher level of accuracy with the same number of iterations than using Backpropagation only. Can be seen in the first trial of breast cancer data with parameters namely hidden layer 5, learning rate of 2 and iteration as much as 5000 resulting in accuracy of $99.3 \%$ with error $0.7 \%$ on Backpropagation Algorithm, while in combination BP \& GSA got accuracy of $99.68 \%$ with error of $0.32 \%$.
\end{abstract}

Keywords: Combination; Accuracy; Artificial Neural Networks; Backpropagation; Gravitational Search Algorithm (GSA)

\section{PENDAHULUAN}

Jaringan saraf tiruan (JST) dapat mengolah atau memproses informasi yang terinspirasi oleh struktur otak manusia [1][2][3]. Jaringan saraf tiruan terdiri dari berbagai macam algoritma salah satunya Algoritma Backpropagation. Algoritma Backpropagation merupakan salah satu algoritma yang sering digunakan dalam kasus prediksi penyakit [4][5][6]. Dalam kasus prediksi, algoritma Backpropagation dapat dikatan sebagai salah satu algoritma yang baik digunakan karena Algoritma Backpropagation memiliki kelebihan yaitu untuk meminimalisir kesulitan dalam lonjakan waktu yang hanya tergantung pada synopsis [7]. Tetapi, berdasarkan referensi yang telah di perlajari bahwa Algoritma Backpropagation ini terdapat sedikit kekurangan yaitu cenderung lama dalam mencapai konvergen untuk mendapatkan tingkat akurasi yang optimum [7][8][9], selain itu Algoritma Backpropagation ini membutuhkan data pelatihan yang cukup besar serta kombinasi algoritma yang digunakan kurang efisien[10][11]. Oleh karena itu fokus dalam penelitian ini dengan kekurangan tersebut Algoritma Backpropagation perlu diperbaiki dengan melakukan kombinasi menggunakan Algoritma lain dengan harapan keakuratan yang didapatkan akan lebih baik bila dibandingkan dengan hanya menggunakan algoritma Backpropagation standard saja.

Dari beberapa lileratur review yang membahas keberhasilan Gravitational Search Algorithm (GSA) yaitu salah satunya yang terdapat pada jurnal berikut [12]. Terlihat pada penelitian tersebut kombinasi Artificial Neural Networks (ANN) dan Gravitational Search Algorithm (GSA) dapat memberikan efektivitas klasifikasi yang lebih baik dari kombinasi dengan menggunakan algoritma lainnya. Inspirasi lain penggunaan Gravitational Search Algorithm (GSA) berdasarkan pada keberhasilan para peneliti dalam menyelesaikan masalah kombinasi untuk 
meningkatkan akurasi, Gravitational Search Algorithm (GSA) memiliki kelebihan ialah kemampuannya dalam menemukan hasil yang lebih optimal dibandingkan dengan algoritma lainnya [13] selain itu kelebihan lain GSA pada masalah kecepatan untuk menghasilkan tingkat akurasi yaitu pada GSA menggunakan memori yang lebih kecil dari algoritma lainnya [14], serta agen yang terdapat didalamnya ikut membantu dalam memperbarui iterasi [15]. Hal ini dapat menunjukkan bahwa GSA baik dan cocok untuk digunakan dalam mengatasi kelemahan pada Algoritma Backpropagation. Sehingga penulis mengusulkan akan mengkombinasikan Algoritma Backpropagation dengan GSA dengan tujuan untuk meningkatkan akurasi. Diharapkan kombinasi Backpropagation dan GSA dapat menghasilkan tingkat akurasi yang lebih tinggi dengan iterasi sama. Kombinasi algoritma Backpropagation dan GSA akan diterapkan untuk memprediksi penyakit. Penyakit yang akan digunakan untuk di prediksi terdiri dari 4 empat data penyakit, yaitu penyakit jantung, penyakit kanker payudara, penyakit diabetes dan penyakit liver.

\section{METODOLOGI PENELITIAN}

\subsection{Gravitational Search Algorithm (GSA)}

Gravitational Search Algorithm (GSA) dapat didefinisikan sebagai sebuah algoritma optimalan yang bergerak berdasarkan aktivitas dari fenomena fisik alam yang berdasarkan pada hukum gerak dan newton gravitasi [16]. Rashedi adalah orang yang pertama yang mengusulkan teori tersebut pada tahun 2009 [13]. GSA dikenal sebagai algoritma berbasis populasi yang disebabkan oleh masa dan kekuatan alam. Algoritma GSA digunakan untuk meningkatkan tingkat kinerja dengan cara membuat keseimbangan tingkat kriteria eksplorasi dan eksploitasi dengan tujuan untuk mengatasi kesulitan bawaan yang ditemukan pada sebagian besar algoritma yang berbasis populasi [13]. Gambar 1. dibawah ini akan menunjukkan proses kerja GSA yang disajikan dalam bentuk flowchart [13].

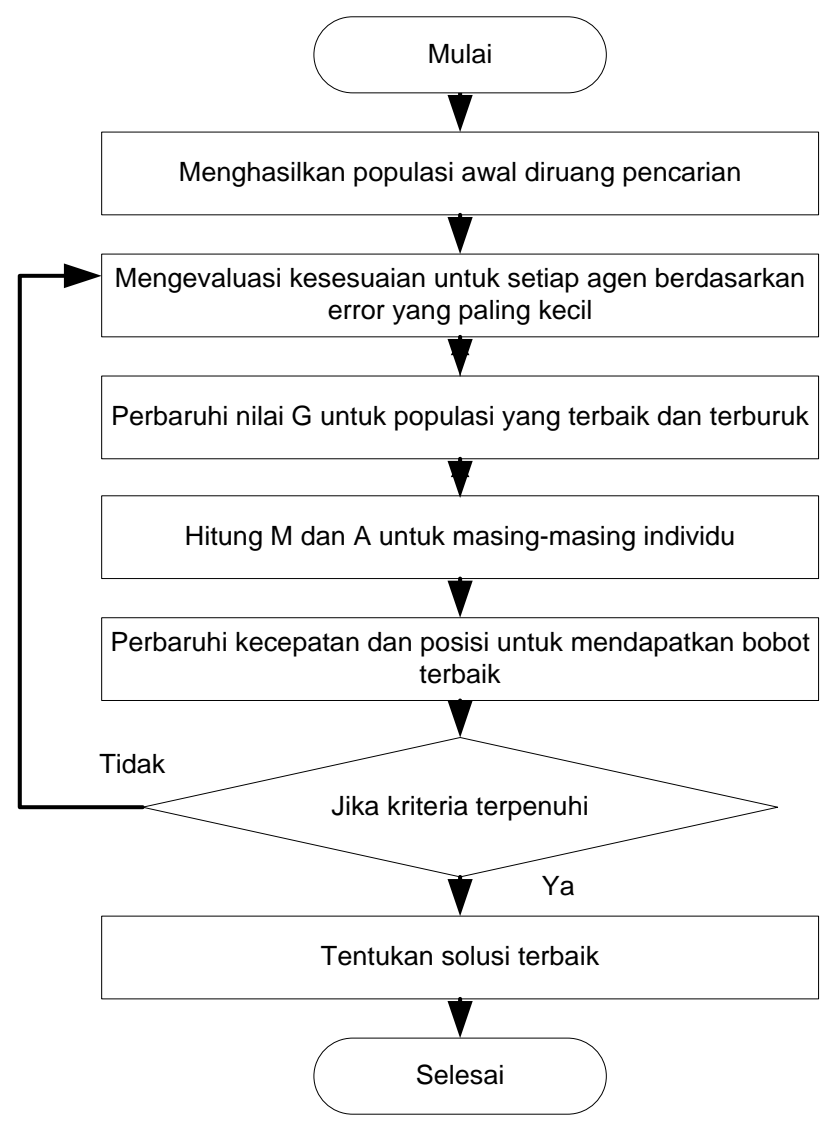

Gambar 1. Kerangka Kerja GSA

\subsection{Dataset}

Pada penelitian ini dataset yang digunakan berupa dataset sekunder. Dataset yang digunakan berasal dari dataset yang sudah ada yang bersumber dari KAGGLE. Dataset yang digunakan terdiri dari empat data penyakit yaitu, penyakit kanker payudara, penyakit diabetes, penyakit jantung dan penyakit liver. dataset penyakit kanker payudara berjumlah 569 data dan memiliki 31 atribut, dataset penyakit diabetes berjumlah 768 data dan memiliki 9 atribut, dataset penyakit jantung berjumlah 303 data dan memiliki 14 atribut sedangkan penyakit liver berjumlah 583 data dan memiliki 11 atribut. Dapat dilihat pada tabe1 1. berikut ini : 
JURNAL MEDIA INFORMATIKA BUDIDARMA

Volume 5, Nomor 1, Januari 2021, Page 90-98

ISSN 2614-5278 (media cetak), ISSN 2548-8368 (media online)

Available Online at https://ejurnal.stmik-budidarma.ac.id/index.php/mib

DOI 10.30865/mib.v5i1.2597

Tabel 1. Jumlah Dataset

\begin{tabular}{ccc}
\hline Dataset & Jumlah Dataset & Jumlah Atribut \\
\hline Penyakit kanker payudara & 569 & 31 \\
Penyakit diabetes & 768 & 9 \\
Penyakit jantung & 303 & 14 \\
Penyakit liver & 583 & 11 \\
\hline
\end{tabular}

\subsection{Data Preprocessing}

Penelitian ini menggunakan dataset yang bersumber dari KAGGLE. Selanjutnya data di preprocessing untuk menghilangkan data yang duplikat dan noise data. Dari data tersebut akan di kategorikan dan dinormalisasikan kemudian data tersebut langsung di prosess menggunakan GSA untuk menentukan bobot terbaik. Hasil bobot terbaik dari GSA akan dikoreksi lebih baik lagi dengan menggunakan Backpropagation. Dari hasil analisis akan diketahui tingkat akurasi dan cara sistem memprediksi penyakit. Langkah terakhir, hasil akan di analisis performansi dan akurasinya dengan memperhatikan Mean Square Error (MSE).

\subsection{Algoritma Backpropagation}

Algoritma Backpropagation yaitu algoritma yang digunakan untuk mengembangkan model Atificial Neural Network [17]. Algoritma Backpropagation terdiri atas tiga lapisan, yaitu lapisan input yang mana pada lapisan input ini data akan diperkenalkan ke dalam jaringan, lapisan tersembunyi data akan di proses, dan pada lapisan output hasil dari lapisan input akan diproduksi [18]. Pada tahapan pelatihan pada algoritma backpropagation melibatkan feedforward pada pola pelatihan input untuk di uji sampai lapisan ouput, setelah itu backpropagation melakukan pengecekan kesalahan dengan aturan mundur untuk di koreksi dan diperbarui [19][20]. Gambar 2. Dibawah ini akan menunjukkan proses kerja GSA yang disajikan dalam bentuk flowchart [21].

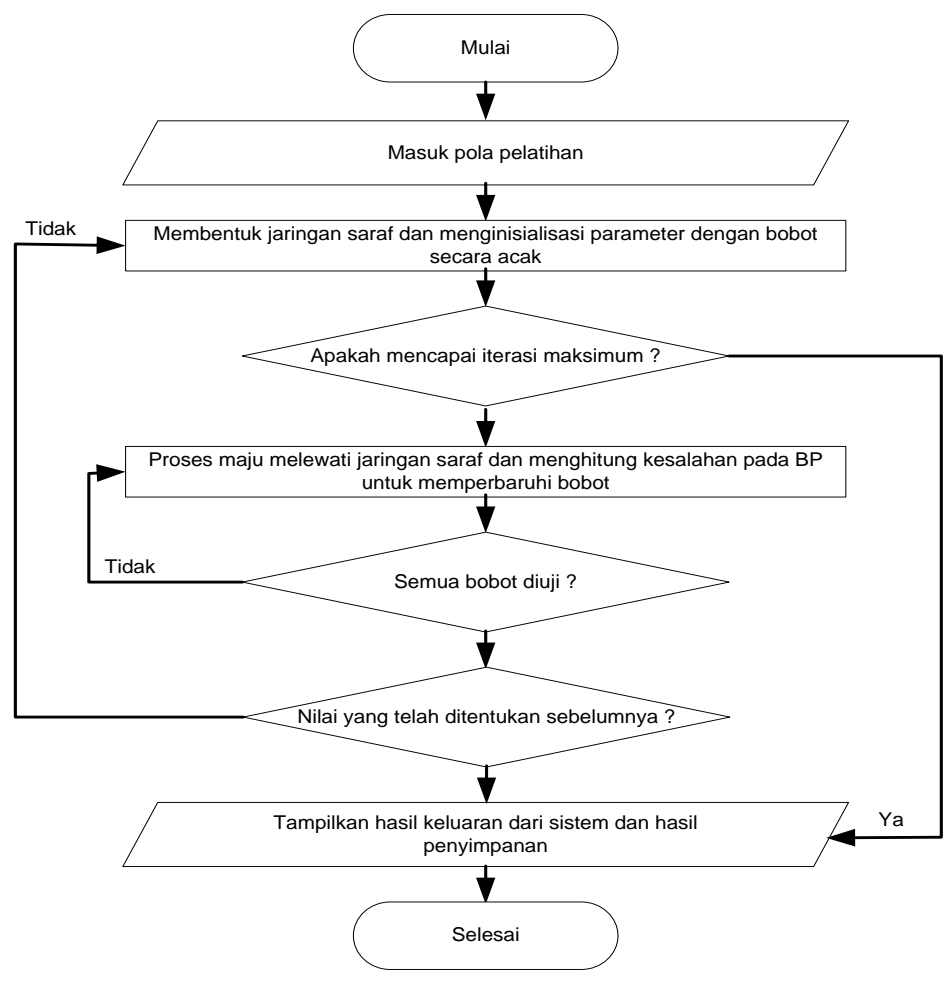

Gambar 2. Kerangka Kerja Backpropagation

\subsection{Kombinasi GSA \& Backpropagation}

Gambar 4 dibawah ini akan menunjukkan alur flowchart bagaimana cara sistem dalam melakukan kombinasi GSA dan Backpropagation. Dimulai dari tahap GSA untuk mencari bobot terbaik dari populasi awal di ruang pencarian berdasarkan hukum gravitasi, selanjutnya dari bobot terbaik yang di dapatkan pada tahap GSA akan di uji kesesuaian untuk setiap agen berdasarkan error yang paling kecil dengan menggunakan feedforward di lapisan input dengan umpan maju setelah itu dengan melakukan umpan balik backpropagation akan mengkoreksi bobot tesebut untuk didapatkan bobot terbaik dalam mendapatkan nilai akurasi yang terbaik. Gambar 3. Dibawah ini akan menunjukkan proses kerja kombinasi GSA \& BP yang disajikan dalam bentuk flowchart. 
JURNAL MEDIA INFORMATIKA BUDIDARMA

Volume 5, Nomor 1, Januari 2021, Page 90-98

ISSN 2614-5278 (media cetak), ISSN 2548-8368 (media online)

Available Online at https://ejurnal.stmik-budidarma.ac.id/index.php/mib DOI 10.30865/mib.v5i1.2597

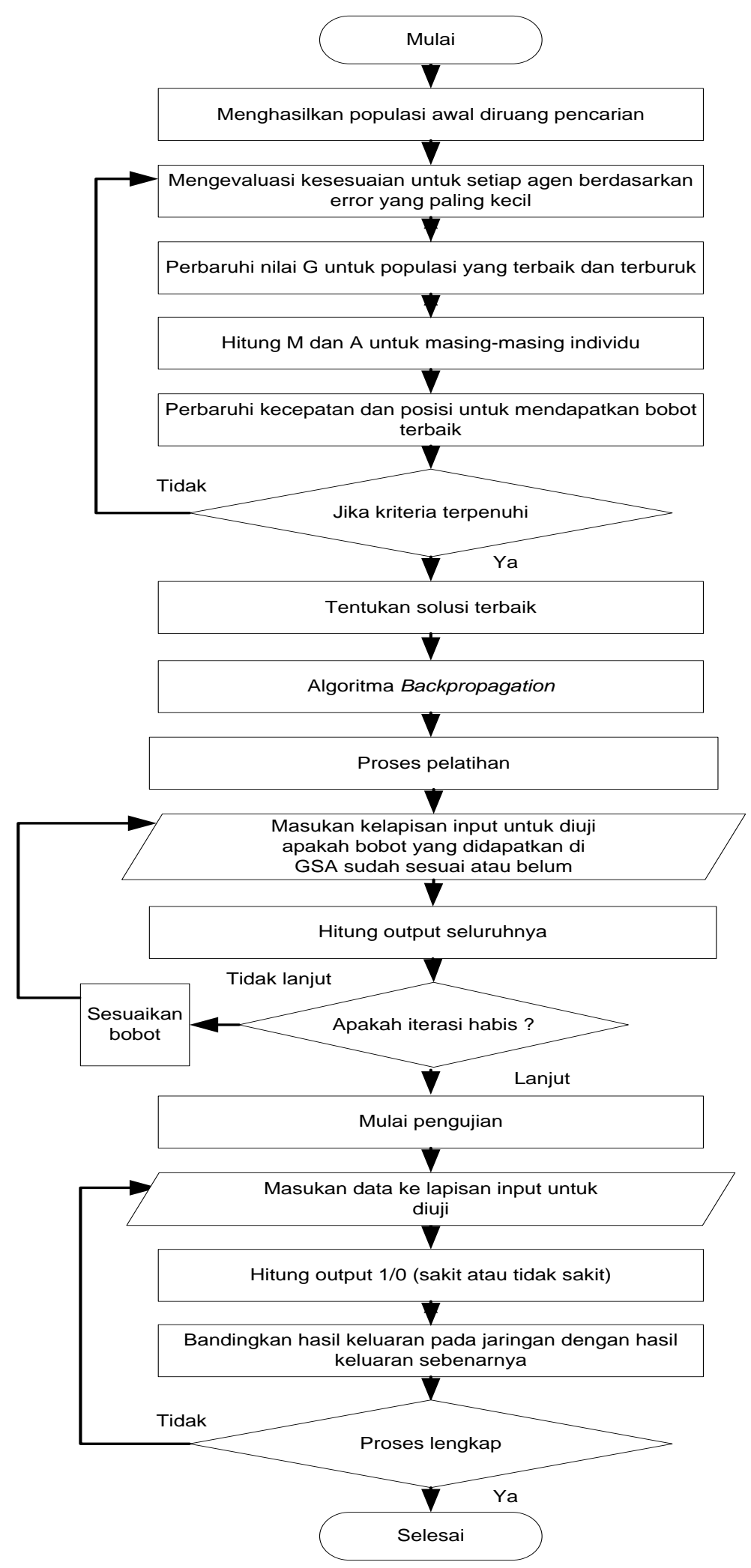

Gambar 3. Kerangka Kerja GSA \& Backpropagation

\section{HASIL DAN PEMBAHASAN}

Penelitian ini membahas kombinasi Algoritma Backpropagation dengan Garvitational Search Algorithm (GSA) dalam meningkatkan akurasi yang di terapkan untuk memprediksi penyakit. Penyakit yang akan di prediksi terdiri dari 4 data penyakit yaitu penyakit jantung, penyakit kanker payudara, penyakit diabetes dan penyakit liver menggunakan dataset yang bersumber dari KAGGLE. Selanjutnya data di preprocessing untuk menghilangkan data yang duplikat dan noise data. Dari data tersebut akan di kategorikan dan di normalisasikan selanjutnya 
langsung di proses menggunakan Gravitational Search Algorithm (GSA) untuk menentukan bobot terbaik dengan mengevaluasi kesesuaian dari populasi di awal pencarian berdasarkan error yang paling kecil. Hasil bobot terbaik dari Gravitational Search Algorithm (GSA) akan dikoreksi lebih baik lagi dengan menggunakan Backpropagation untuk didapatkan bobot terbaik dalam mendapatkan nilai akurasi yang terbaik. Dari hasil analisis akan diketahui tingkat akurasi dan cara sistem dalam memprediksi penyakit. Langkah terakhir, hasil akan di analisis performansi dan akurasinya dengan memperhatikan Mean Square Error (MSE). Hasil yang didapatkan berupa tingkat akurasi bagaimana cara sistem dalam memprediksi penyakit.. Pada grafik dan tabel dibawah ini akan memperlihatkan tingkat perbandingan menggunakan Backpropagation saja dengan kombinasi Backpropagation dan Gravitational Search Algorithm (GSA). Dengan mengambil 3 sampel data dari setiap data penyakit dimana setiap percobaan yang dilakukan memiliki parameter hidden layer, learning rate dan NN iterasi yang sama. Nilai parameter yang ditentukan pada setiap percobaan sebelumnya telah dilakukan percobaan terlebih dahulu sehingga nilai tersebut baik digunakan. hasil yang didapatkan menjelaskan bagaimana perbandingan yang dihasilkan antara menggunakan Backpropagation saja dengan kombinasi Backpropagation dan GSA, sehingga kita dapat mengambil kesimpulan algoritma mana dari kedua algoritma tersebut yang paling baik digunakan dalam masalah memprediksi penyakit.

\subsection{Dataset Penyakit Jantung}

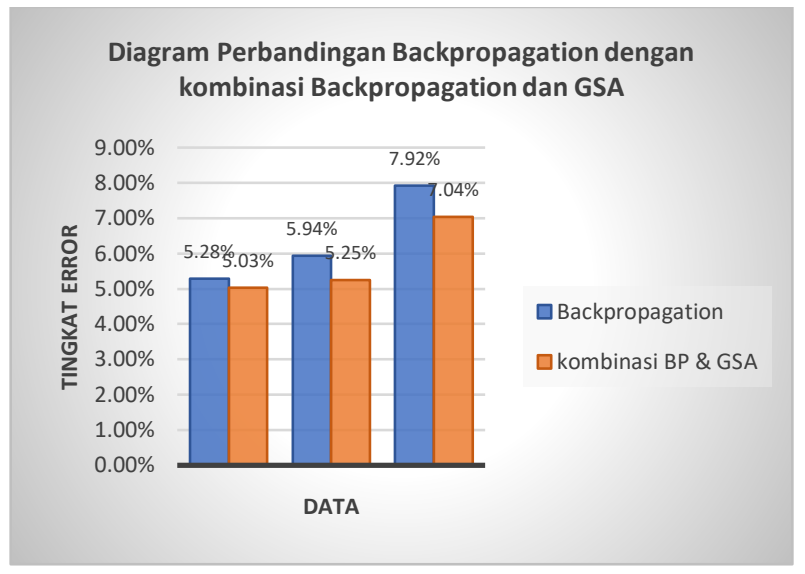

Gambar 4. Diagram Perbandingan BP dengan Kombinasi BP\&GSA

Terlihat pada gambar 4. diagram perbandingan Backpropagation dengan kombinasi Backpropagation \& Gravitational Search Algorithm di atas terdapat 3 kali percobaan dari data penyakit jantung. Pada tabel 2. dibawah ini akan menjelaskan hasil perbandingan BP dengan kombinasi BP dan GSA.

Tabel 2. Diagram Perbandingan BP dengan Kombinasi BP\&GSA

\begin{tabular}{|c|c|c|c|c|c|c|c|c|c|c|}
\hline \multirow[b]{2}{*}{$\begin{array}{l}\text { Perco } \\
\text { baan }\end{array}$} & \multicolumn{4}{|c|}{ Backpropagation } & \multicolumn{6}{|c|}{ Kombinasi BP \& GSA } \\
\hline & $\begin{array}{l}\mathrm{H} \\
\mathrm{L}\end{array}$ & LR & $\begin{array}{c}\text { ITERASI_N } \\
\mathrm{N}\end{array}$ & $\begin{array}{c}\text { ERRO } \\
\text { R }\end{array}$ & $\begin{array}{l}\mathrm{H} \\
\mathrm{L}\end{array}$ & LR & $\begin{array}{c}\text { ITERASI_N } \\
\mathrm{N}\end{array}$ & $\begin{array}{c}\text { POP_GS } \\
\text { A }\end{array}$ & $\begin{array}{c}\text { GSA_ITERAS } \\
\text { I }\end{array}$ & $\begin{array}{c}\text { ERRO } \\
\text { R }\end{array}$ \\
\hline 1 & 15 & 4 & 2000 & $5.281 \%$ & 15 & 4 & 2000 & 50 & 1 & $5.03 \%$ \\
\hline 2 & 20 & 2.5 & 2000 & $5.94 \%$ & 20 & 2.5 & 2000 & 50 & 20 & $5.25 \%$ \\
\hline 3 & 10 & 2 & 2000 & $7.921 \%$ & 10 & 2 & 2000 & 50 & 10 & $7.04 \%$ \\
\hline
\end{tabular}

Terlihat pada tabel 2. Perbandingan BP dengan kombinasi BP dan GSA. Hasil data penyakit jantung yang terdiri dari 303 data dan 14 fitur dengan menggunakan Algoritma Backpropagation serta kombinasi Algoritma Backpropagation dan GSA dalam 3 percobaan yang di lakukan. Pada percobaan pertama dengan parameter yaitu Hidden layer 15, Learning Rate 4 dan NN iterasi 2000 menghasilkan nilai akurasi $94.719 \%$ dengan tingkat error sebesar 5.281\% untuk Algoritma Backpropagation sedangkan pada kombinasi Algoritma Backpropagation dengan GSA dengan parameter yaitu Hidden layer 15, Learning Rate 4, NN iterasi 2000 populasi GSA 50 dan iterasi GSA 1 menghasilkan nilai akurasi $94.97 \%$ dengan tingkat error sebesar $5.03 \%$. Pada percobaan kedua dengan parameter yaitu Hidden layer 20, Learning Rate 2.5 dan NN iterasi 2000 menghasilkan nilai akurasi $94.6 \%$ dengan tingkat error sebesar 5.94\% untuk Algoritma Backpropagation sedangkan pada kombinasi Algoritma Backpropagation dan GSA dengan parameter yaitu Hidden layer 20, Learning Rate 2.5, NN iterasi 2000 populasi GSA 50 dan iterasi GSA 20 menghasilkan nilai akurasi 94.75\% dengan tingkat error sebesar 5.25\%. Pada percobaan ketiga dengan parameter yaitu Hidden layer 10, Learning Rate 2 dan NN iterasi 2000 menghasilkan nilai akurasi $92.079 \%$ dengan tingkat error sebesar 7.921\% untuk Algoritma Backpropagation sedangkan pada kombinasi Algoritma Backpropagation dan GSA dengan parameter yaitu Hidden layer 10, Learning Rate 2, NN iterasi 2000 populasi GSA 50 dan iterasi GSA 10 menghasilkan nilai akurasi 92.96\% dengan tingkat error sebesar $7.04 \%$ 
JURNAL MEDIA INFORMATIKA BUDIDARMA

Volume 5, Nomor 1, Januari 2021, Page 90-98

ISSN 2614-5278 (media cetak), ISSN 2548-8368 (media online)

Available Online at https://ejurnal.stmik-budidarma.ac.id/index.php/mib

DOI 10.30865/mib.v5i1.2597

\subsection{Dataset Penyakit Kanker Payudara}

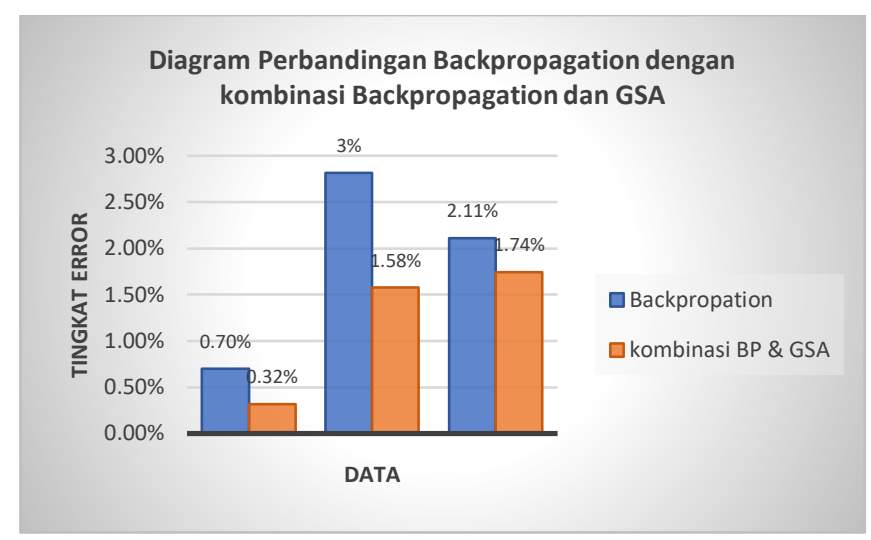

Gambar 5. Diagram Perbandingan BP dengan Kombinasi BP\&GSA

Terlihat pada gambar 5. diagram perbandingan Backpropagation dengan kombinasi Backpropagation \& Gravitational Search Algorithm di atas terdapat 3 kali percobaan dari data penyakit kanker payudara. Pada tabel 3. dibawah ini akan menjelaskan perbandingan BP dengan kombinasi BP \& GSA.

Tabel 3. Diagram Perbandingan BP dengan Kombinasi BP\&GSA

\begin{tabular}{|c|c|c|c|c|c|c|c|c|c|c|}
\hline \multirow{2}{*}{$\begin{array}{l}\text { Perco } \\
\text { baan }\end{array}$} & \multicolumn{4}{|c|}{ Backpropagation } & \multicolumn{6}{|c|}{ Kombinasi BP \& GSA } \\
\hline & $\begin{array}{l}\mathrm{H} \\
\mathrm{L}\end{array}$ & $\begin{array}{l}\mathrm{L} \\
\mathrm{R}\end{array}$ & $\begin{array}{c}\text { ITERASI_N } \\
\mathrm{N}\end{array}$ & $\begin{array}{c}\text { ERRO } \\
\text { R }\end{array}$ & $\begin{array}{l}\mathrm{H} \\
\mathrm{L}\end{array}$ & $\begin{array}{l}\mathrm{L} \\
\mathrm{R}\end{array}$ & $\begin{array}{c}\text { ITERASI_N } \\
\mathrm{N}\end{array}$ & $\begin{array}{c}\text { POP_GS } \\
\text { A }\end{array}$ & $\underset{\text { I }}{\text { GSA_ITERAS }}$ & $\begin{array}{c}\text { ERRO } \\
\text { R }\end{array}$ \\
\hline 1 & 5 & 2 & 5000 & $0.7 \%$ & 5 & 2 & 5000 & 50 & 10 & $0.32 \%$ \\
\hline 2 & 3 & 1 & 2000 & $3 \%$ & 3 & 1 & 2000 & 50 & 20 & $1.58 \%$ \\
\hline 3 & 7 & 1 & 2000 & $2.11 \%$ & 7 & 1 & 2000 & 50 & 10 & $1.74 \%$ \\
\hline
\end{tabular}

Terlihat pada tabel 3. Perbandingan BP dengan kombinasi BP \& GSA. Hasil data penyakit kanker payudara yang terdiri dari 569 data dan 31 fitur dengan menggunakan Algoritma Backpropagation serta kombinasi Algoritma Backpropagation dan GSA dalam 3 percobaan yang di lakukan. Pada percobaan pertama dengan parameter yaitu Hidden layer 5, Learning Rate 2 dan NN iterasi 5000 menghasilkan nilai akurasi 99.3\% dengan tingkat error sebesar $0.70 \%$ untuk Algoritma Backpropagation sedangkan pada kombinasi Algoritma Backpropagation dan GSA dengan parameter yaitu Hidden layer 5, Learning Rate 2, NN iterasi 5000 populasi GSA 50 dan iterasi GSA 10 menghasilkan nilai akurasi $99.68 \%$ dengan tingkat error sebesar $0.32 \%$. Pada percobaan kedua dengan parameter yaitu Hidden layer 3, Learning Rate 1 dan NN iterasi 2000 menghasilkan nilai akurasi $97 \%$ dengan tingkat error sebesar 3\% untuk Algoritma Backpropagation sedangkan pada kombinasi Algoritma Backpropagation dan GSA dengan parameter yaitu Hidden layer 3, Learning Rate 1, NN iterasi 2000 populasi GSA 50 dan iterasi GSA 20 menghasilkan nilai akurasi $98.42 \%$ dengan tingkat error sebesar $1.58 \%$. Pada percobaan ketiga dengan parameter yaitu Hidden layer 7, Learning Rate 1 dan NN iterasi 2000 menghasilkan nilai akurasi $97.89 \%$ dengan tingkat error sebesar 2.11\% untuk Algoritma Backpropagation sedangkan pada kombinasi Algoritma Backpropagation dan GSA dengan parameter yaitu Hidden layer 7, Learning Rate 1, NN iterasi 2000 populasi GSA 50 dan iterasi GSA 10 menghasilkan nilai akurasi 98.26\% dengan tingkat error sebesar $1.74 \%$.

\subsection{Dataset Penyakit Diabetes}

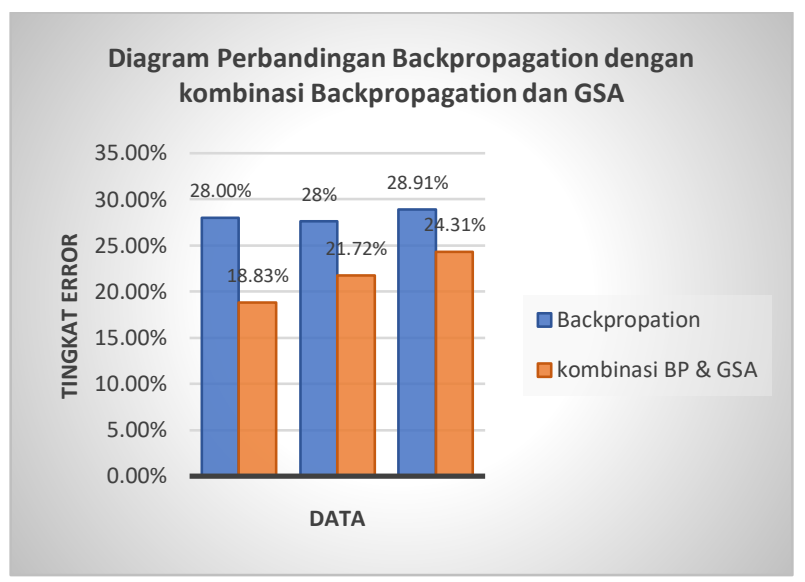

Gambar 6. Diagram Perbandingan BP dengan Kombinasi BP\&GSA 
JURNAL MEDIA INFORMATIKA BUDIDARMA

Volume 5, Nomor 1, Januari 2021, Page 90-98

ISSN 2614-5278 (media cetak), ISSN 2548-8368 (media online)

Available Online at https://ejurnal.stmik-budidarma.ac.id/index.php/mib

DOI 10.30865/mib.v5i1.2597

Terlihat pada gambar 6. diagram perbandingan Backpropagation dengan kombinasi Backpropagation \& Gravitational Search Algorithm di atas terdapat 3 kali percobaan dari data penyakit diabetes. Pada tabel 4. dibawah ini akan menjelaskan perbandingan BP dengan kombinasi BP \& GSA

Tabel 4. Diagram Perbandingan BP dengan Kombinasi BP\&GSA

\begin{tabular}{ccccccccccc}
\hline $\begin{array}{c}\text { Perco } \\
\text { baan }\end{array}$ & HL & LR & ITERASI_NN & ERROR & HL & LR & ITERASI_NN & POP_GSA & GSA_ITERASI & ERROR \\
\hline 1 & 20 & 1 & 2000 & $27.99 \%$ & 20 & 1 & 2000 & 5 & 1 & $18.83 \%$ \\
2 & 15 & 1 & 2000 & $28 \%$ & 15 & 1 & 2000 & 50 & 1 & $21.72 \%$ \\
3 & 15 & 0.5 & 2000 & $28.91 \%$ & 15 & 0.5 & 2000 & 50 & 1 & $24.31 \%$ \\
\hline
\end{tabular}

Terlihat pada tabel 4. Perbandingan BP dengan kombinasi BP \& GSA. Hasil data penyakit diabetes yang terdiri dari 768 data dan 9 fitur dengan menggunakan Algoritma Backpropagation serta kombinasi Algoritma Backpropagation dan GSA dalam 3 percobaan yang di. Pada percobaan pertama dengan parameter yaitu Hidden layer 20, Learning Rate 1 dan NN iterasi 2000 menghasilkan nilai akurasi 72.01\% dengan tingkat error sebesar 27.99\% untuk Algoritma Backpropagation sedangkan pada kombinasi Algoritma Backpropagation dan GSA dengan parameter yaitu Hidden layer 20, Learning Rate 1, NN iterasi 2000 populasi GSA 5 dan iterasi GSA 1 menghasilkan nilai akurasi $81.17 \%$ dengan tingkat error sebesar $18.83 \%$. Pada percobaan kedua dengan parameter yaitu Hidden layer 15, Learning Rate 1 dan NN iterasi 2000 menghasilkan nilai akurasi 72\% dengan tingkat error sebesar 28\% untuk Algoritma Backpropagation sedangkan pada kombinasi Algoritma Backpropagation dan GSA dengan parameter yaitu Hidden layer 15, Learning Rate 1, NN iterasi 2000 populasi GSA 50 dan iterasi GSA 1 menghasilkan nilai akurasi $78.28 \%$ dengan tingkat error sebesar $21.72 \%$. Pada percobaan ketiga dengan parameter yaitu Hidden layer 15, Learning Rate 0.5 dan NN iterasi 2000 menghasilkan nilai akurasi 71.09\% dengan tingkat error sebesar 28.91\% untuk Algoritma Backpropagation sedangkan pada kombinasi Algoritma Backpropagation dan GSA dengan parameter yaitu Hidden layer 15, Learning Rate 0.5, NN iterasi 2000 populasi GSA 50 dan iterasi GSA 1 menghasilkan nilai akurasi $75.69 \%$ dengan tingkat error sebesar $24.31 \%$.

\subsection{Dataset Penyakit Liver}

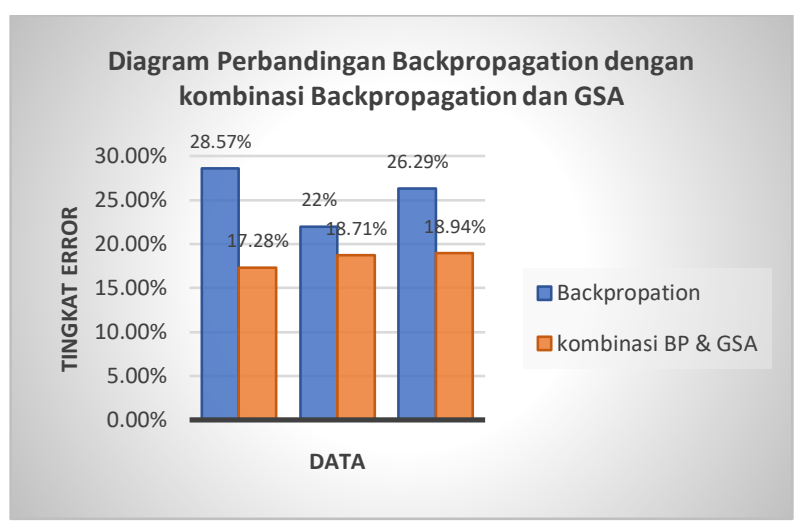

Gambar 7. Diagram Perbandingan BP dengan Kombinasi BP\&GSA

Terlihat pada gambar 7. diagram perbandingan Backpropagation dengan kombinasi Backpropagation \& Gravitational Search Algorithm di atas terdapat 3 kali percobaan dari data penyakit liver. Pada tabel 5. dibawah ini akan menjelaskan perbandingan BP dengan kombinasi BP \& GSA

Tabel 5. Diagram Perbandingan BP dengan Kombinasi BP\&GSA

\begin{tabular}{|c|c|c|c|c|c|c|c|c|c|c|}
\hline \multirow{2}{*}{$\begin{array}{c}\text { Percobaa } \\
n\end{array}$} & \multicolumn{4}{|c|}{ Backpropagation } & \multicolumn{6}{|c|}{ Kombinasi BP \& GSA } \\
\hline & $\mathrm{H}$ & $\begin{array}{l}\mathrm{L} \\
\mathrm{R}\end{array}$ & ITERASI_N & $\begin{array}{c}\text { ERRO } \\
\mathrm{R}\end{array}$ & $\mathrm{H}$ & L & ITERASI_N & POP_GS & GSA_ITERAS & ERRO \\
\hline & & 1. & 7500 & $50-70$ & & $\frac{\pi}{1 .}$ & 10 & $\mathrm{~A}$ & & \\
\hline 1 & 25 & 5 & 7500 & $28.57 \%$ & 25 & 5 & 7500 & 50 & 10 & $17.28 \%$ \\
\hline 2 & 25 & $\begin{array}{l}0 . \\
8\end{array}$ & 7500 & $22 \%$ & 25 & $\begin{array}{l}0 . \\
8\end{array}$ & 2000 & 50 & 10 & $18.71 \%$ \\
\hline 3 & 25 & $\begin{array}{l}0 . \\
5\end{array}$ & 7500 & $26.29 \%$ & 25 & $\begin{array}{l}0 . \\
5\end{array}$ & 7500 & 50 & 1 & $18.94 \%$ \\
\hline
\end{tabular}

Terlihat pada tabel 5, perbandingan BP dengan kombinasi BP \& GSA. Hasil data penyakit liver yang terdiri dari 583 data dan 11 fitur dengan menggunakan Algoritma Backpropagation serta kombinasi Algoritma Backpropagation dan GSA dalam 3 percobaan yang di lakukan. Pada percobaan pertama dengan parameter yaitu Hidden layer 25, Learning Rate 1.5 dan NN iterasi 7500 menghasilkan nilai akurasi $71.43 \%$ dengan tingkat error 
sebesar 28.57\% untuk Algoritma Backpropagation sedangkan pada kombinasi Algoritma Backpropagation dan GSA dengan parameter yaitu Hidden layer 25, Learning Rate 1.5, NN iterasi 7500 populasi GSA 50 dan iterasi GSA 10 menghasilkan nilai akurasi $82.72 \%$ dengan tingkat error sebesar 17.28\%. Pada percobaan kedua dengan parameter yaitu Hidden layer 25, Learning Rate 0.8 dan NN iterasi 7500 menghasilkan nilai akurasi $78 \%$ dengan tingkat error sebesar 22\% untuk Algoritma Backpropagation sedangkan pada kombinasi Algoritma Backpropagation dan GSA dengan parameter yaitu Hidden layer 25, Learning Rate 0.8, NN iterasi 7500 populasi GSA 50 dan iterasi GSA 10 menghasilkan nilai akurasi $81.29 \%$ dengan tingkat error sebesar $18.71 \%$. Pada percobaan ketiga dengan parameter yaitu Hidden layer 25, Learning Rate 0.5 dan NN iterasi 7500 menghasilkan nilai akurasi $73.71 \%$ dengan tingkat error sebesar 26.29\% untuk Algoritma Backpropagation sedangkan pada kombinasi Algoritma Backpropagation dan GSA dengan parameter yaitu Hidden layer 25, Learning Rate 0.5, NN iterasi 7500 populasi GSA 50 dan iterasi GSA 1 menghasilkan nilai akurasi $81.06 \%$ dengan tingkat error sebesar $18.94 \%$.

\section{KESIMPULAN}

Dapat di lihat dari hasil penelitian dengan melakukan kombinasi Algoritma Backpropagation dan Gravitational Search Algorithm (GSA) hasil yang didapat bahwa kombinasi keduanya dapat menghasilkan tingkat akurasi yang lebih baik dilihat dari tingkat error yang lebih kecil dengan jumlah iterasi yang sama dibandingkan hanya menggunakan Backpropagation saja. Dapat dilihat pada percobaan pertama data penyakit kanker payudara dengan parameter yaitu hidden layer 5, learning rate 2 dan iterasi 5000 menghasilkan akurasi sebesar 99,3\% dengan error $0.7 \%$ pada Algoritma Backpropagation, sedangkan pada kombinasi BP \& GSA mendapat akurasi sebesar 99.68 $\%$ dengan error sebesar $0.32 \%$ serta dapat diambil kesimpulan hasil dari data 4 penyakit yang telah di teliti bahwa kombinasi BP \& GSA cocok diterapkan pada data penyakit kanker payudara karena menghasilkan tingkat akurasi yang lebih baik dari data penyakit lainnya.

\section{REFERENCES}

[1] S. Bhaumik and M. Kamaraj, "Artificial neural network and multi-criterion decision making approach of designing a blend of biodegradable lubricants and investigating its tribological properties," Proc. Inst. Mech. Eng. Part J J. Eng. Tribol., 2020, doi: 10.1177/1350650120965754.

[2] R. M. Sadek et al., "Parkinson's Disease Prediction Using Artificial Neural Network," vol. 3, no. 1, pp. 1-8, 2019, [Online]. Available: http://dstore.alazhar.edu.ps/xmlui/handle/123456789/302.

[3] J. J. Pangaribuan, "Mendiagnosis Penyakit Diabetes Melitus Dengan Menggunakan Metode Extreme Learning Machine," J. ISD, vol. 2, no. 2, pp. 2528-5114, 2016.

[4] P. Sehgal and K. Taneja, "Predictive Data Mining for Diagnosis of Thyroid Disease using Neural Network," vol. 3, no. 2, pp. 75-80, 2015.

[5] M. Durairaj, "PREDICTION OF DIABETES USING BACK PROPAGATION ALGORITHM," vol. 1, no. 8, pp. 2125,2015

[6] T. Karayilan and Ö. Kiliç, "Prediction of Heart disease using neural network," 2nd Int. Conf. Comput. Sci. Eng. UBMK 2017, pp. 719-723, 2017, doi: 10.1109/UBMK.2017.8093512.

[7] A. Wanto, "Optimasi Prediksi Dengan Algoritma Backpropagation Dan Conjugate Gradient Beale-Powell Restarts," J. Nas. Teknol. dan Sist. Inf., vol. 3, no. 3, pp. 370-380, 2018, doi: 10.25077/teknosi.v3i3.2017.370-380.

[8] C. S. Chen and S. L. Su, "Resilient back-propagation neural network for approximation 2-D GDOP," Proc. Int. MultiConference Eng. Comput. Sci. 2010, IMECS 2010, vol. II, no. 1, pp. 900-904, 2010.

[9] Riska Yanu Fa'arifah and Z. Busrah, "Backpropagation Neural Network untuk Optimasi Akurasi pada Prediksi Financial Distress Perusahaan,” J. Inf. Sains dan Teknol., vol. 2, no. April, pp. 101-110, 2017.

[10] I. Muzakkir, A. Syukur, and I. Novita Dewi, "Peningkatan Akurasi Algoritma Backpropagation Dengan Seleksi Fitur Particle Swarm Optimization Dalam Prediksi Pelanggan Telekomunikasi Yang Hilang," Pseudocode, vol. 1, no. 1, pp. 1-10, 2015, doi: 10.33369/pseudocode.1.1.1-10.

[11] R. Bala and D. Kumar, "Classification Using ANN : A Review,” vol. 13, no. 7, pp. 1811-1820, 2017.

[12] S. M. K. Chaitanya and P. R. Kumar, Detection of Chronic Kidney Disease by Using Arti fi cial Neural Networks and Gravitational Search Algorithm. Springer Singapore.

[13] E. Rashedi, H. Nezamabadi-pour, and S. Saryazdi, "GSA: A Gravitational Search Algorithm," Inf. Sci. (Ny)., vol. 179, no. 13, pp. 2232-2248, 2009, doi: 10.1016/j.ins.2009.03.004.

[14] V. Kumar, J. K. Chhabra, and D. Kumar, "Automatic cluster evolution using gravitational search algorithm and its application on image segmentation," Eng. Appl. Artif. Intell., vol. 29, pp. 93-103, 2014, doi: 10.1016/j.engappai.2013.11.008.

[15] E. Rashedi, H. Nezamabadi-Pour, and S. Saryazdi, "Filter modeling using gravitational search algorithm," Eng. Appl. Artif. Intell., vol. 24, no. 1, pp. 117-122, 2011, doi: 10.1016/j.engappai.2010.05.007.

[16] C. Purcaru, R. E. Precup, D. Iercan, L. O. Fedorovici, R. C. David, and F. Dragan, "Optimal robot path planning using gravitational search algorithm," Int. J. Artif. Intell., vol. 10, no. 13 S, pp. 1-20, 2013.

[17] P. Antwi et al., "Estimation of biogas and methane yields in an UASB treating potato starch processing wastewater with backpropagation artificial neural network," Bioresour. Technol., vol. 228, pp. 106-115, 2017, doi: 10.1016/j.biortech.2016.12.045.

[18] D. Huang and Z. Wu, "Forecasting outpatient visits using empirical mode decomposition coupled with backpropagation artificial neural networks optimized by particle swarm optimization," PLoS One, vol. 12, no. 2, pp. 1-17, 2017, doi: 
JURNAL MEDIA INFORMATIKA BUDIDARMA

Volume 5, Nomor 1, Januari 2021, Page 90-98

ISSN 2614-5278 (media cetak), ISSN 2548-8368 (media online)

Available Online at https://ejurnal.stmik-budidarma.ac.id/index.php/mib DOI 10.30865/mib.v5i1.2597

10.1371/journal.pone.0172539.

[19] J. Tarigan, Nadia, R. Diedan, and Y. Suryana, "Plate Recognition Using Backpropagation Neural Network and Genetic Algorithm,” Procedia Comput. Sci., vol. 116, pp. 365-372, 2017, doi: 10.1016/j.procs.2017.10.068.

[20] S. P. Siregar and A. Wanto, "Analysis of Artificial Neural Network Accuracy Using Backpropagation Algorithm In Predicting Process (Forecasting)," IJISTECH (International J. Inf. Syst. Technol., vol. 1, no. 1, p. 34, 2017, doi: 10.30645/ijistech.v1i1.4.

[21] V. K. Ojha, P. Dutta, H. Saha, and S. Ghosh, "Detection of Proportion of Different Gas Components Present in Manhole Gas Mixture Using Backpropagation Neural Network,” Technology, vol. 37, no. Icint, pp. 11-15, 2012. 